\title{
PENERAPAN TEKNOLOGI INFORMASI DAN KOMUNIKASI (ICT) UNTUK PEMBELAJARAN BAHASA INGGRIS DI PRODI ARSITEKTUR
}

\author{
Maria Istiqoma 1 \\ Mahasiswa Prodi Arsitektur, Fak. Teknik Sipil dan Perencanaan, ITN Malang \\ e-mail:mariaistiqoma@gmail.com \\ Tutut Nani Prihatmi 2 \\ Dosen Prodi Arsitektur, Fak. Teknik Sipil dan Perencanaan, ITN Malang \\ e-mail: misstiyu@gmail.com
}

\begin{abstract}
ABSTRAK
Memasuki era revolusi industri 4.0 atau revolusi industri dunia keempat, teknologi informasi telah menjadi basis dalam kehidupan manusia, Teknologi Informasi dan Komunikasi (ICT) telah menjadi bagian dari kehidupan kita sehari-hari terutama kedalam kurilkulum pendidikan sebagai salah satu teknik pembelajaran.

Terkait dengan hal tersebut, fokus penelitian ini adalah sebagai jawaban atas tantangan Pembelajaran Bahasa Inggris memasuki era revolusi industri 4.0 untuk mengetahui apakah ITN Malang, terutama Program Studi Arsitektur dilengkapi dengan sarana prasarana Teknologi Informasi dan Komunikasi (ICT) dan bagaimana Teknologi Informasi dan Komunikasi (ICT) bisa diterapkan dalam Pembelajaran Bahasa Inggris.

Penelitian ini merupakan penelitian deskriptif dengan metode pengumpulan data melalui kuesioner dan wawancara. Penelitian ini dilakukan di ITN Malang pada semester ganjil 2018/2019. Populasi dalam penelitian ini adalah mahasiswa Arsitektur ITN Malang angkatan 2018 yang mengambil mata kuliah Bahasa Inggris pada semester ganjil 2018/2019.
\end{abstract}

Kata kunci : Teknologi Informasi dan Komunikasi (ICT), pembelajaran Bahasa Inggris.

\begin{abstract}
Emerging the 4.0 industrial revolution era, information technology has been the basis in human life. Moreover, Information and Communication Technology (ICT) has become part of our daily lives especially when it appears into the educational curriculum as one of the learning techniques. Related to this, the focus of this research is in response to the challenges of English Language Learning entering the era of the industrial revolution 4.0 to find out whether ITN Malang, especially the Architecture Study Program is equipped with Information and Communication Technology (ICT) infrastructure facilities and how Information and Communication Technology (ICT)) can be applied in English Language Learning.
\end{abstract}

PAWON: Jurnal Arsitektur, Nomor 01- Volume IV, Januari-Juni 2020, ISSN 2597-7636 
This research was a descriptive study which employed data collection methods through questionnaires and interviews. This research was conducted at ITN Malang in odd semester 2018/2019. The population in this study were students of Architecture ITN Malang 2018 who took English subject in odd semester 2018/2019.

\section{Keywords : 3-5 keywords, Algorithm A, Algorithms B, complexity}

\section{PENDAHULUAN}

Memasuki era revolusi industri 4.0 atau revolusi industri dunia keempat, teknologi informasi telah menjadi basis dalam kehidupan manusia, Teknologi Informasi dan Komunikasi (ICT) telah menjadi bagian dari kehidupan kita sehari-hari, hal ini juga masuk kedalam kurilkulum pendidikan sebagai salah satu teknik pembelajaran. Dunia pendidikan yang ingin lebih maju dan kompetitif harus didukung dengan penggunaan Teknologi Informasi dan Komunikasi (ICT) sebagai bagian dari proses pengajaran dan pembelajaran. Bahasa Inggris sebagai bahasa internasional yang menyatukan komunikasi secara global tidak lepas dengan terintegrasinya penggunaan Teknologi Informasi dan Komunikasi (ICT).

Menurut Dang (2011) teknologi sebagai sarana yang menyediakan informasi lebih cepat ketika dibutuhkan dan mudah diakses untuk kebutuhankebutuhan pendidikan. Jadi, mahasiswa yang terbiasa dalam lingkungan yang didukung dengan penggunaan Teknologi dan Informasi (ICT) memiliki banyak kesempatan dalam memperkaya dan mengembangkan pengalaman dan keahliannya melalui penggunaan teknologi baik di dalam dan diluar kelas. Begitu juga dikutip dari halaman Kemenristekdikti (https://ristekdikti.go.id) ada lima elemen krusial yang harus menjadi perhatian dan akan dilaksanakan oleh Kemenristekdikti untuk mendorong pertumbuhan ekonomi dan daya saing bangsa di era Revolusi Industri 4.0, yang salah satunya yaitu: Persiapan sistem pembelajaran yang lebih inovatif di perguruan tinggi seperti penyesuaian kurikulum pembelajaran, dan meningkatkan kemampuan mahasiswa dalam hal data Information Technology (IT), Operational Technology (OT), Internet of Things (IoT), dan Big Data Analitic, mengintegrasikan objek fisik, digital dan manusia untuk menghasilkan lulusan perguruan tinggi yang kompetitif dan terampil terutama dalam aspek data literacy, technological literacy and human literacy. Hal ini merupakan tantangan yang besar juga bagi pengajar Bahasa Inggris untuk untuk bereksplorasi dengan teknologi.

Maka dari itu, untuk menjawab tantangan Revolusi Industri 4.0 tersebut penulis mencoba meneliti Penerapan Teknologi Informasi dan Komunikasi (ICT) di dalam pembelajaran Bahasa Inggris di ITN Malang terutama pada

PAWON: Jurnal Arsitektur, Nomor 01- Volume IV, Januari-Juni 2020, ISSN 2597-7636 
Program Studi Arsitektur. Jadi dalam penelitian ini, peneliti iingin mengetahui apakah Program Studi Arsitektur ITN Malang dilengkapi dengan sarana prasarana Teknologi Informasi dan Komunikasi (ICT) yang mendukung untuk pembelajaran Bahasa Inggris dan bagaimana Teknologi Informasi dan Komunikasi (ICT) diterapkan dalam Pembelajaran Bahasa Inggris.

\section{TINJAUAN PUSTAKA}

\subsection{Teknologi Informasi dan Komunikasi (ICT)}

Menurut Hennessy, Ruthven and Brindley (2005, p. 2) Istilah Teknologi Informasi dan Komunikasi (ICT) mencakup berbagai perangkat keras (komputer desktop dan portabel, teknologi proyeksi, kalkulator, pencatatan data dan peralatan perekaman digital), aplikasi perangkat lunak (perangkat lunak generik, sumber daya multimedia), sarana sistem telekomunikasi dan informasi (Intranet, Internet). Jadi bila dapat disimpulkan Teknologi Informasi dan Komunikasi (ICT). Beberapa contoh Teknologi Informasi dan Komunikasi (ICT) yaitu: IWB, komputer, perangkat lunak pembelajaran bahasa berbasis komputer (CALL), aplikasi kantor (Words, PowerPoint, drawing tools dll.), Internet - situs web dan perangkat lunak yang dapat diunduh, buku pelajaran CD-ROM, DVD player, ponsel, kamus elektronik, kamera dan video digital, perekam DAT, kamera dokumen, proyektor data. Selanjutnya, begitu banyak variasi teknologi terkini yang bisa digunakan dan dimanfaatkan serta menjadi pilihan untuk disesuaikan dengan kebutuhan.

\subsection{Konsep Teknologi Informasi dan Komunikasi (ICT) dalam Pembelajaran Bahasa Inggris}

Seperti pernyataan dari Cakiki (2016) dengan berkembangnya Teknologi Informasi dan Komunikasi (ICT) sebagai alat baru dalam pengajaran bahasa, guru dan metodologi EFL diharapkan dapat mengadopsi pandangan baru tentang pengintegrasian keterampilan Teknologi Informasi dan Komunikasi (ICT) dasar di kelas EFL secara tepat. Ini merupakan prasyarat untuk melengkapi pembelajaran bahasa dengan keterampilan teknologi yang diperlukan. Penerapan Teknologi Informasi dan Komunikasi (ICT) membutuhkan keterampilan dan strategi bahasa tertentu. Memperkenalkan Teknologi Informasi dan Komunikasi (ICT) ke dalam kelas bahasa memiliki implikasi besar untuk reformasi kurikulum, pengajaran di kelas dan pembelajaran mahasiswa. Maka dari itu, implementasi Teknologi Informasi dan Komunikasi (ICT) ke dalam pembelajaran dengan konteks yang lebih nyata pada saat ini menjadi lebih penting dan krusial daripada sebelumnya, dikarenakan kekuatan dan kemampuannya yang semakin 
meningkat memicu perubahan lingkungan atau atmosfer dalam pembelajaran Bahasa Inggris.

Lebih lanjut lagi, konsep pembelajaran Bahasa Inggris berbasis Teknologi Informasi dan Komunikasi (ICT) menurut Faridi (2009) dapat diwujudkan dengan perangkat pembelajaran seperti: (1) Kerangka Konsep (KTSP), (2) Silabus-RPP, (3) Materi Ajar, (4) Media/ Alat Peraga, dan (5) Evaluasi Pembelajaran. Faridi (2009) juga menambahkan lagi sebagai media atau alat peraga pembelajaran ada beberapa aplikasi yang ditawarkan dalam Pembelajaran Bahasa Inggris seperti: 1. E-learning (Web Course, Web Centric Course, Web Enhanced Course), 2. E-Library, 3. Virtual University, 4. EdukasiNet, 5. Jardiknas. Adapun perangkat pembelajaran berbasis Teknologi Informasi dan Komunikasi (ICT) serta aplikasi yang telah disebutkan diatas merupakan pilihan yang bisa diterapkan yang disesuaikan dengan capaian pembelajaran.

\subsection{Konsep Teknologi Informasi dan Komunikasi (ICT) dalam Pembelajaran Bahasa Inggris}

Kemampuan berbahasa Inggris tidak bisa dilepaskan dengan penguasaan empat skill (four skills) yaitu: Mendengarkan (Listening), Berbicara (Speaking), Menulis (Writing), dan Membaca (Reading) dan Teknologi Informasi dan Komunikasi (ICT) bisa digunakan dalam memfasilitasi dan meningkatkan kemampuan empat keahlian tersebut:

\subsubsection{Listening}

Kemampuan mendengarkan atau Listening merupakan kunci yang sangat penting dalam Berbahasa Inggris seperti yang diutarakan oleh Nachoua:

Nachoua (2012) reports that the skill of listening is of key significance for English language learners to acquire. It is also a very intricate skill to teach. The concept of pronunciation, whether that is to understand or produce language, also raises problems for non-native speakers. Using CALL (Computer Assisted Language Learning) is a way to motivate language learners to take a dynamic role in their learning instead of acting as passive listeners.

Berdasarkan Nachoua (2012) kemampuan mendengarkan atau Listening dengan menggunakan CALL (Computer Assisted Language Learning) merupakan salah satu cara untuk memotivasi pelajar bahasa untuk mengambil peran dinamis dalam pembelajaran walaupun bertindak sebagai pendengar pasif. Adapun ada beberapa pilihan untuk mengembangkan kemampuan mendengarkan (Listening) dengan menggunakan instrument multimedia seperti digital stories, Mp3, Recording atau Podcast. 


\subsubsection{Speaking}

Kemampuan Berbicara atau Speaking dilihat sebagai lingua Franca Berbahasa Inggris seperti yang diutarakan oleh Drigas:

As English today is regarded as a lingua franca, the skill of speaking has become a skill of paramount significance to acquire (Drigas, 2014).

Adapun beberapa aplikasi yang bisa digunakan seperti yang diutarakan oleh Hashemi (2011) yaitu penggunaan Oovo dan Skype, adalah bahwa peserta didik dapat memperoleh manfaat dari pengalaman belajar yang otentik daripada rutinitas mereka yang biasa, yang pada gilirannya akan memotivasi mereka untuk meminta komunikasi yang lebih nyata, lebih banyak kesempatan untuk menginternalisasi bahasa.

As Hashemi explains, the use of Oovoo and Skype apart from enabling users to interact with pre-recorded messages, also provide learners with the option of synchronous chat, allowing the creation of a virtual class of three to six users, depending on the kind of subscription - free or paid respectively. Another benefit provided by these two tools is that learners can benefit from authentic learning experiences rather than their usual routine, which will in turn motivate them to ask for more real communication hence, more chances to internalise language

\subsubsection{Writing}

Kemampuan Menulis atau Writing dilihat sebagai seperti yang diutarakan oleh Drigas (2011):

Writing can be perplexing for many students since it requires correct use of grammar. Unlike spoken language, written language cannot use gestures or body language to explain what it is that needs to be understood or conveyed.

Jadi menurut Drigas kemampuan Menulis atau Writing dapat menyulitkan bagi banyak pelajar bahasa karena penggunaan tata bahasa yang benar harus benar dan tidak seperti speaking, bahasa tertulis tidak bisa menggunakan gerak tubuh atau bahasa tubuh untuk menjelaskan apa yang perlu dipahami atau disampaikan.

The use of blog software and Tweeter are tools that can help students practice written language, engage with the language they wish to learn and of course to share their thoughts or feelings 
and reflect on them. Promoting writing instruction through such an entertaining way enables more production of written language which might not have been produced otherwise. Students who also blogged rather than merely attending an in-class session showed better results from those who only received in-class writing instruction. Teachers should make use of this tool as it enhances writing performance while it is not limited within school walls as it can take place anywhere. The result the students who blogged seem to have was an improvement over those who did not, which indicates the value of the integration of this tool. Tweeting also seems to be a valuable tool to initiate the creation of community bonds, hence allowing the learners find out more about each other and build community bonds. In addition, when implementing forums, blogs and wikis at the same time, this seems to have positive results on students' learning progress since this blended approach allows them to study the differences which may occur in ways of expressing in English when using written language (Arslan et al, Lomicka et al. and Miyazoe et al).

Adapun Arslan, Lomicka dan Miyazoe mengungkapkan bahwa penggunaan blog dan Tweeter adalah alat yang dapat membantu siswa mempraktikkan bahasa tertulis dengan bahasa yang ingin mereka pelajari dan juga untuk berbagi pemikiran atau perasaan mereka. Aplikasi lain yang bisa digunakan seperti app.readable.io, sli.do, bubbl.us.

\subsubsection{Reading}

Kemampuan Membaca atau Reading diutarakan oleh Drigas (2011):

Online reading is a task that appears to be necessary for the 21st century students. Therefore, the creation of a Web-based reading program called 'English Reading Online' was created to narrow the gap between reading and comprehension using online reading strategies. The effective use of reading strategies is known to amplify a reader's understanding.

Maka dari itu menurut Drigas, online reading bisa jadi sangat penting untuk pembelajar bahasa pada abad ke 21 dan pembuatan program membaca berbasis web yang secara efektif disebut 'Bahasa Inggris Membaca Online' diciptakan untuk mempersempit kesenjangan antara membaca dan pemahaman menggunakan strategi membaca online. 


\section{METODE PENELITIAN}

Pendekatan yang digunakan untuk penelitian ini adalah pendekatan kualitatif, yaitu dengan menggunakan data yang terkumpul dalam bentuk kata atau gambar, bukan dalam bentuk angka. Berdasarkan Bogdan dan Taylor (1975) yang dikutip oleh Moleong (2007:4) mengemukakan bahwa metodologi kualitatif sebagai prosedur penelitian yang menghasilkan data deskriptif berupa kata-kata tertulis atau lisan dari orang-orang dan perilaku yang dapat diamati. Dengan demikian, penelitian kualitatif bertujuan mendapatkan gambaran menyeluruh atas suatu hal menurut pandangan manusia yang diteliti. Penelitian kualitatif berhubungan dengan ide, persepsi, pendapat atau kepercayaan orang yang diteliti yang tidak dapat diukur melalui angka.

Adapun jenis penelitian yang dilakukan adalah penelitian studi kasus (case study). Studi kasus merupakan penelitian kualitatif di mana peneliti melakukan eksplorasi secara mendalam terhadap program, kejadian, proses, aktifitas, terhadap satu atau lebih orang (Mustamid, 2015).

Penelitian ini akan dilaksanakan pada waktu pembelajaran mata kuliah Bahasa Inggris di Program Studi Arsitektur Institut Teknologi Nasional Malang pada semester ganjil 2018/2019. Adapun Metode Pengumpulan Data yang digunakan adalah: Kuisioner dan wawancara.

Kuisioner (angket) berisi sejumlah pertanyaan tertulis yang dipakai untuk menggali informasi dari responden atau hal-hal yang responden ketahui. Dalam penelitian ini, kuesioner digunakan untuk mendapatkan data tentang sarana prasarana Teknologi Informasi dan Komunikasi (ICT) yang mendukung untuk pembelajaran Bahasa Inggris. Kuisoner ini berupa Google Form berisi pertanyaan yang wajib dijawab responden melalui link yang disebarkan kepada mahasiswa.

Menurut Sutopo (2006:72) Teknik Wawancara dalam penelitian kualitatif dilakukan secara mendalam (in-depth interview) yaitu sebuah proses untuk menggali informasi yang diinginkan dengan melakukan tanya jawab secara langsung antara interviewer (pewawancara) dan interviewe (yang diwawancara). Wawancara dilakukan sebagai alat untuk pembuktian (rechecking) atas informasi yang diperoleh sebelumnya. Wawancara yang dilakukan dalam penelitian ini menggunakan pedoman wawancara bebas terpimpin. Wawancara bebas terpimpin adalah upaya mengajukan pertanyaan yang dikemukakan bebas, yang pertanyaannya tidak terpaku pada pedoman wawancara tentang masalah-masalah pokok dalam penelitian. Wawancara tersebut kemudian dapat dikembangkan sesuai dengan kondisi di lapangan (Sutrisno Hadi, 1994: 207).Terwawancara atau

PAWON: Jurnal Arsitektur, Nomor 01- Volume IV, Januari-Juni 2020, ISSN 2597-7636 
responden dipilih sesuai kebutuhan. Responden pada penelitian ini meliputi: Dosen Bahasa Inggris Prodi Arsitektur, Sampel/perwakilan mahasiswa.

Subjek utama dalam penelitian ini adalah seluruh mahasiswa prodi Arsitektur yang mengambil mata kuliah Bahasa Inggris pada semester ganjil tahun akademik 2018/2019 ini. Sebanyak 113 mahasiswa Arsitektur akan digunakan sebagai subyek. Adapun objek penelitian atau sasaran yang akan diteliti dalam penelitian ini difokuskan pada kajian terhadap kontribusi fasilitas ICT dalam efektifitas pembelajaran Bahasa Inggris.

Dalam penelitian kualitatif, analisa data merupakan proses pelacakan dan pengaturan secara sistematis transkip wawancara, catatan lapangan, dan data lainnya yang dikumpulkan untuk meningkatkan pemahaman tersebut agar dapat diinterpretasikan temuannya kepada orang lain (Zuriah, 2006: 217). Penelitian ini menggunakan analisa data sebagai berikut:a.Instrumen penelitian yang digunakan adalah kuisioner dan wawancara. b. Pengolahan data tes dilakukan oleh tim peneliti sebagai instrumen penelitian. c. Hasil kuisioner dan wawancara dijabarkan dalam data deskriptif. Data kemudian dikelompokkan ke dalam topik yang sama kemudian direduksi untuk mengambil kesimpulan umum. d. Setelah data tereduksi, maka langkah selanjutnya adalah menyajikan data. penyajian data biasanya dilakukan dengan menyajikan uraian singkat, bagan, hubungan antar kategori, flowchart, dan sejenisnya. Bentuk yang digunakan pada data kualitatif adalah penyajian data dalam bentuk teks naratif. e. Penarikan Kesimpulan dan Verifikasi. Verifikasi dilakukan dengan melihat kembali reduksi data maupun display data sehingga kesimpulan yang diambil tidak menyimpang. 


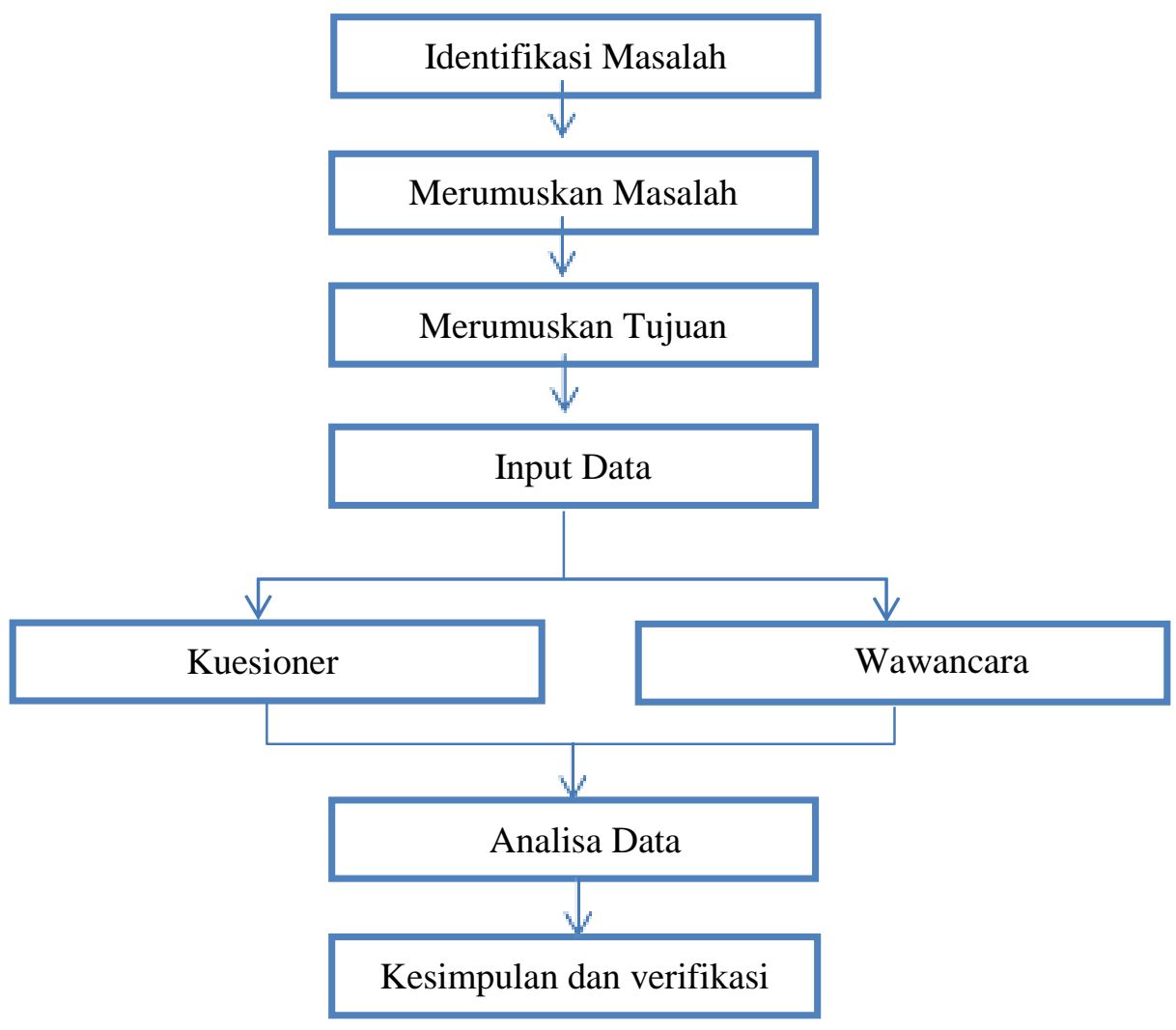

Gambar. 1

Diagram Alir Penelitian

Sumber: Analisis Penulis, 2019 


\section{HASIL DAN PEMBAHASAN}

\subsection{Respon dari kuisioner}

1. Bagaimana pendapat anda tentang: a. Hubungan Mahasiswa dengan dosen dalam Proses Pembelajaran di kelas

45 tangoupan

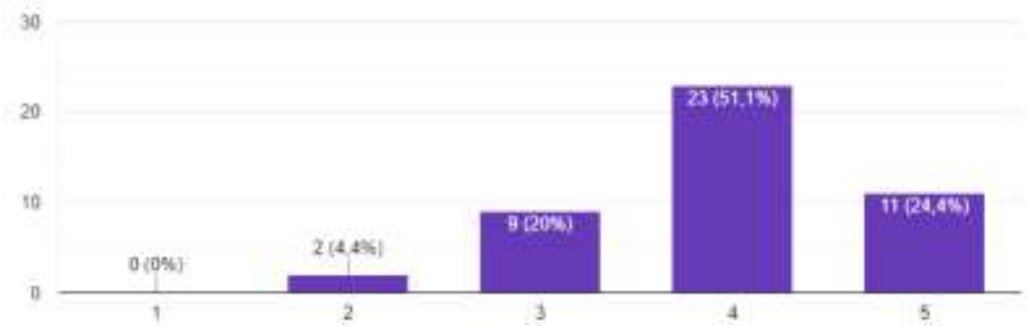

Gambar. 2

Grafik hubungan mahasiswa dengan dosen dalam pembelajaran.

Sumber: Data Kuesioner, 2019

Grafik tertinggi sebanyak $23(51,1 \%)$ menunjukkan bahwa hubungan mahasiswa dengan dosen terjalin dengan baik yang merupakan esensi utama dalam proses pembelajaran di dalam kelas.

b. Materi perkuliahan disampaikan dengan jelas

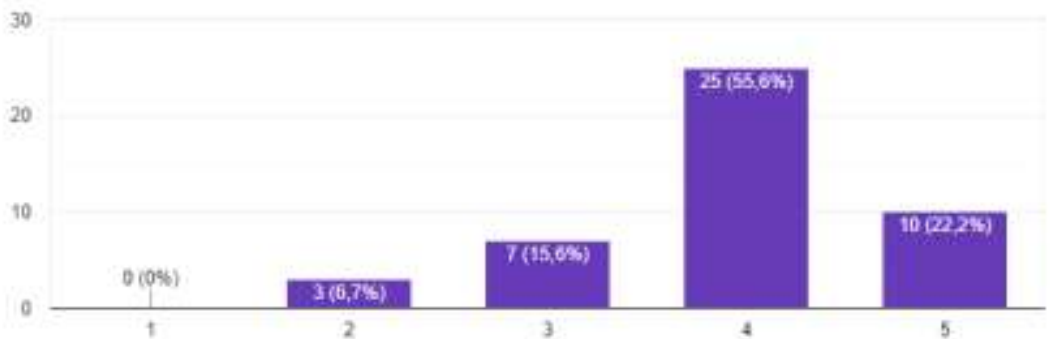

Gambar. 3

Grafik penyampaian materi dalam pembelajaran

Sumber: Data Kuesioner, 2019

Grafik tertinggi sebanyak 25 (55,6\%) menunjukkan bahwa materi perkuliahan disampaikan dengan baik. 
c. Adanya fasilitas pendukung menggunakan teknologi informasi dan komunikasi dalam pembelajaran Bahasa Inggris di setiap kelas

45 taingrapar

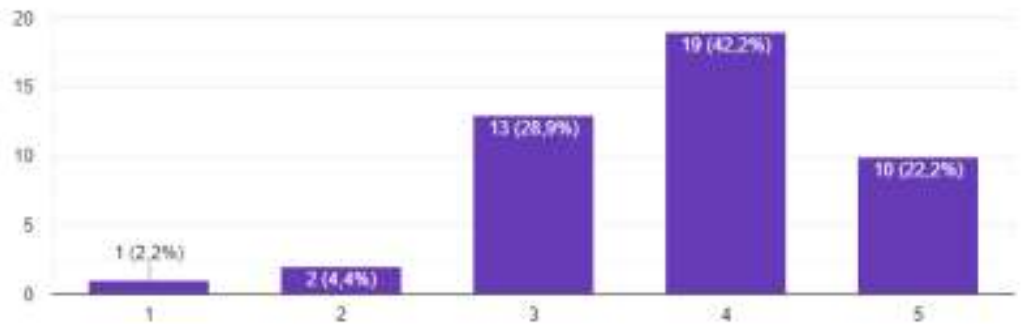

Gambar. 4

Grafik adanya fasilitas teknologi informasi dan komunikasi dalam pembelajaran Sumber: Data Kuesioner, 2019

Grafik tertinggi sebanyak 19 (42,2\%) menunjukkan bahwa fasilitas pendukung menggunakan teknologi informasi dan komunikasi dalam pembelajaran Bahasa Inggris di kelas sudah baik.

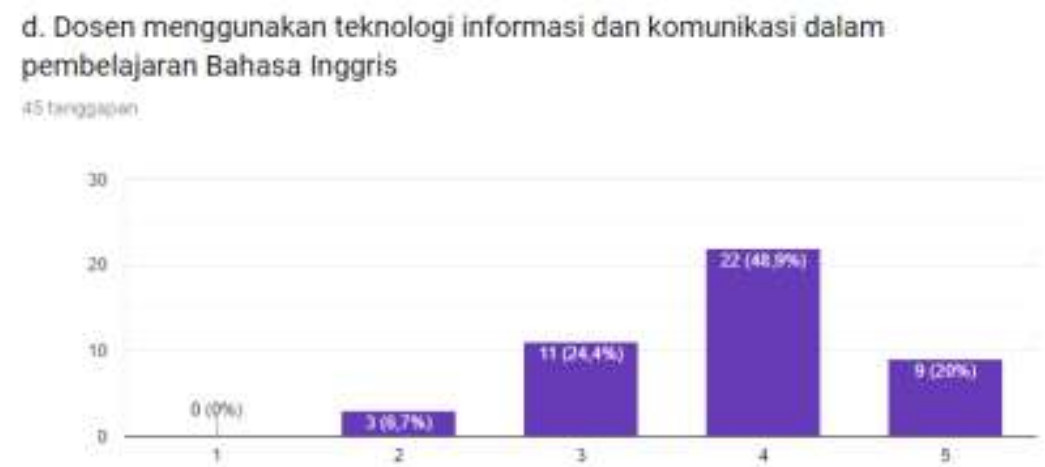

Gambar. 5

Grafik penggunaan teknologi informasi dan komunikasi oleh dosen Sumber: Data Kuesioner, 2019

Grafik tertinggi sebanyak 22 (48,9\%) menunjukkan bahwa penggunaan teknologi informasi dan komunikasi dalam pembelajaran Bahasa Inggris di kelas oleh dosen sudah dilaksanakan dengan baik. 


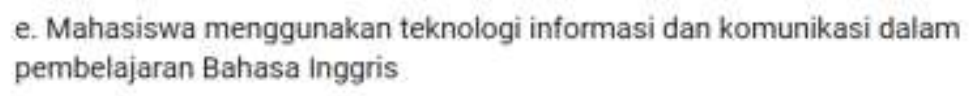

pembelajaran Bahasa Inggris

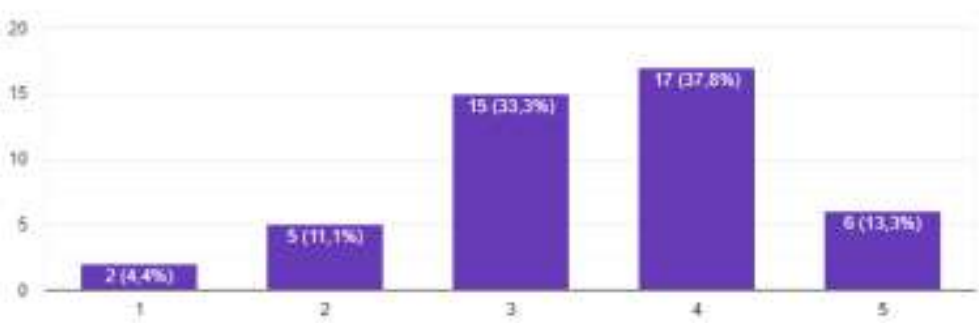

Gambar. 6

Grafik penggunaan teknologi informasi dan komunikasi oleh mahasiswa Sumber: Data Kuesioner, 2019

Grafik tertinggi sebanyak 17 (37,8\%) menunjukkan bahwa penggunaan teknologi informasi dan komunikasi dalam pembelajaran oleh mahasiswa sudah dilaksanakan dengan baik.

2. Dari pengalaman pembelajaran yang pernah anda dapatkan di kelas, penggunaan teknologi informasi dan komunikasi dalam pembelajaran Bahasa Inggris yang sering digunakan adalah:
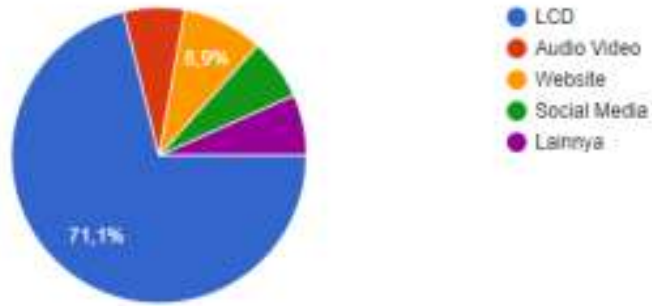

Gambar. 7

Grafik penggunaan teknologi informasi dan komunikasi oleh mahasiswa Sumber: Data Kuesioner, 2019

Dari grafik diatas, responden memberikan respon mengenai penggunaan teknologi informasi dan komunikasi dalam pembelajaran Bahasa Inggris yang sering digunakan oleh mahasiswa di kelas sebanyak $71,1 \%$ menyatakan menggunakan LCD , 8,9\% Website, dan lain- lain menggunakan Audio Video, Social Media. Bisa dilihat bahwa penggunaan LCD menempati porsi yang besar sehingga pemanfaatan Teknologi yang lain belum tergali secara maksimal. 


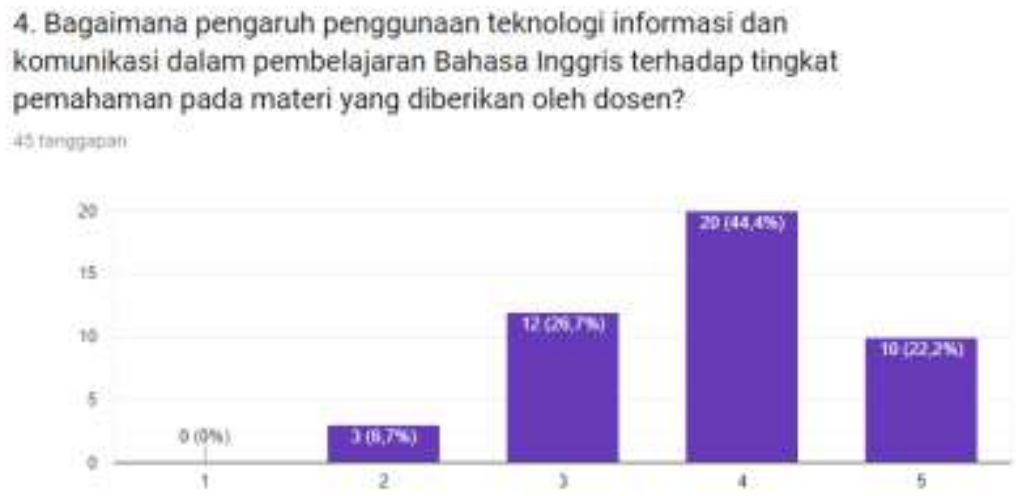

Gambar. 8

Grafik pengaruh penggunaan teknologi informasi dan komunikasi pada mahasiswa Sumber: Data Kuesioner, 2019

Responden memberikan respon mengenai pengaruh teknologi informasi dan komunikasi dalam pembelajaran Bahasa Inggris terhadap tingkat pemahaman pada materi yang diberikan oleh dosen sebanyak $10(22$, $2 \%)$ menyatakan sangat baik, $20(44.4 \%)$ baik, $12(26,7 \%)$ rata-rata dan 3 $(6,7 \%)$ buruk. Grafik tertinggi menunjukkan bahwa Penggunaan teknologi informasi dan komunikasi memiliki pengaruh terhadap mahasiswa dalam menyerap materi Pembelajaran.

\section{Menurut anda, seberapa penting penggunaan teknologi informasi dan komunikasi dalam pembelajaran Bahasa Inggris?}

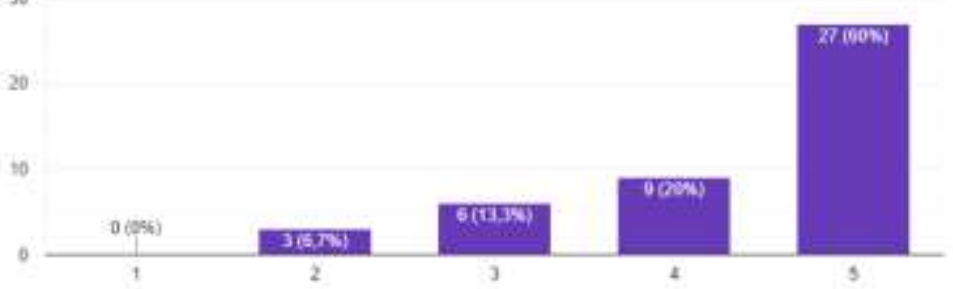

Gambar. 9

Grafik pentingnya penggunaan teknologi informasi dan komunikasi pada mahasiswa Sumber: Data Kuesioner, 2019

Responden memberikan respon mengenai pentingnya penggunaan teknologi informasi dan komunikasi dalam pembelajaran Bahasa Inggris sebanyak $27(60 \%)$ menyatakan sangat baik , $9(20 \%), 6(13,3 \%)$ rata-rata dan $3(6,7 \%)$ buruk. 


\subsection{Deksripsi Hasil Wawancara}

Wawancara yang telah dilakukan terhadap dosen Bahasa Inggris dan 10 mahasiswa menunjukkan hasil yang tidak terlalu beragam. Terdapat banyak kesamaan jawaban dalam 5 poin pertanyaan yang diajukan.

\section{Apakah menurut Anda ICT sudah cukup digunakan dalam} perkuliahan Bahasa Inggris di prodi Arsitektur ITN Malang?

Setidaknya 40\% mahasiswa menyatakan sudah cukup, sementara 60 menyatakan belum. Mereka menginginkan agar ke depan pemakaian ICT lebih dimaksimalkan.

\section{Apakah menurut Anda penggunaan ICT akan membantu Anda dalam mendapatkan hasil belajar yang maksimal di dalam kelas?}

Setidaknya $90 \%$ responden menjawab kemungkinan besar "ya", karena mendapatkan variasi baru dalam perkuliahan agar tidak bosan menerima pembelajaran. $10 \%$ menjawab biasa saja.

\section{Apakah Anda merasa lebih mudah dalam memahami materi speaking yang diajarkan saat dosen menggunakan ICT dalam perkuliahan? Berikan alasannya.}

Setidaknya $90 \%$ responden menyatakan "ya". Mereka berpendapat bahwa dengan bantuan visual apalagi audio visual, mereka lebih tertarik untuk mengikuti perkuliahan daripada mendengarkan perkuliahan konvensional. Karena lebih bisa fokus, bisa melihat materi maupun instruksi dengan jelas.

Pertanyaan kuisioner yang diberikan kepada mahasiswa mengarah pada hubungan yang terjalin antara dosen dan mahasiwa dalam pembelajaran di kelas yang menunjukkan bahwa, hubungan yang baik terjalin ketika adanya sarana komunikasi yang memungkinkan untuk berkomunikasi secara lisan atau tertulis, baik online atau offline, baik secara audio ataupun visual. Instruksi serta langkah- langkah yang diberikan dosen juga sangat penting untuk disampaikan secara jelas dan terstruktur di dalam penyamapian materi ataupun pemberian tugas.

Fasilitas dalam penggunaan Teknologi Informasi dan Komunikasi (ITC) pada saat ini memungkinkan hal tersebut terjadi dan tidak terbatas, hal tersebut mendapat sambutan yang menarik, baik dari dosen maupun mahasiswa dimana pada saat ini menuntut kemudahan dan efisiensi. Namun, kendala yang mungkin terjadi ketika implementasi metode ini di kelas adalah: jaringan internet yang kurang memadai, LCD kurang berfungsi dengan baik atau tidak adanya perawatan dalam sarana dan prasarana yang menunjang, serta instruksi yang kurang jelas. 


\section{KESIMPULAN}

Berdasarkan hasil penelitian dan pembahasan, dapat diambil simpulan bahwa hasil kuesioner menunjukkan adanya fasilitas penggunaan Teknologi Komunikasi dan Informasi (ICT) dalam proses pembelajaran di kelas dianggap sangatlah penting bagi mahasiswa, ketika hubungan antara dosen dan mahasiswa berjalan baik, penyampaian materi juga bisa tersampaikan dengan baik. Penggunaan Teknologi Komunikasi dan Informasi (ICT) sebagian besar masih menggunakan media pembelajaran LCD dan masih sedikit yang menggunakan websites dan lain-lain yang memerlukan koneksi internet yang stabil dan bagus. Hasil wawancara menunjukkan bahwa penggunaan Teknologi Komunikasi dan Informasi (ICT) perlu diperbanyak lagi di dalam kelas karena dapat memberikan hasil yang maksimal serta memudahkan mahasiswa dalam menyerap materi pembelajaran di kelas karena dianggap lebih menarik daripada metode perkuliahan konvensional.

\section{DAFTAR PUSTAKA}

Abdurrachman Faridi. 2009. Inovasi Pembelajaran Bahasa Inggris Berbasis ICT Dalam Rangka Meningkatkan Mutu Pendidikan, Lembaran IImu Kependidikan Jilid 38, No. 1, Juni 2009.

Asabere, N. Y. \& Enguah, S. E. 2012. Integration of expert systems in mobile learning. International. Journal of Information and Communication Technology Research, 2 (1), 55-61.

Cakici, Dilek. 2016. The use of ICT in teaching English as a foreign language. Participatory Educational Research (PER), 73-77.

Dang, XT. 2011. Factors influencing teachers' use of ICT in language teaching: A case study of Hanoi University, Master's Thesis, Vietnam.

Hennessy, S., Ruthven, K. \&Brindley, S. 2005. Teacher perspectives on integrating ICT into subject teaching: Commitment, constraints, caution andchange.http://www.educ.cam.ac.uk/research/projects/istl/WP042.p df.

H., Nachoua. 2012. Computer-Assisted Language Learning for Improving Students'Listening Skill.' International Conference on Education and Educational Psychology (ICEEPSY 2012), Procedia - Social and Behavioral Sciences 69, pp. 1150 - 1159 (2012). 
H.B. Sutopo. 2006. Metodologi Penelitian Kualitatif: Dasar teori dan Terapannya dalam Penelitian. Surakarta: Universitas Sebelas Maret.

Istiqoma, Maria. 2017. Preliminary Study: Eksplorasi Layout Tempat Duduk untuk Pembelajaran Bahasa Inggris di Program Studi Arsitektur. Malang: Spectra.

L., Lomicka \& G., Lord. 2012. A tale of tweets: Analyzing microblogging among language learners. System vol. 40 pp.48-63. Elsevier Ltd.

M., Hashemi, \& M., Azizinezhad. 2011. The Capabilities of Oovoo and Skype for Language Education. Procedia-Social and Behavioral Sciences, 28, 50-53 (2011b). http://dx.doi.org/10.1016/ j.sbspro.2011.11.010

Prihatmi, Tutut Nani. 2017. English Academic Writing Bagi Mahasiswa di Institut Teknologi Nasional Malang: Hambatan dan Solusi. Seminar Nasional Inovasi dan Aplikasi Teknologi di Industri 2017. Malang: LPPM ITN Malang.

R. "., Arslan, \& A., "ahin-Kızıl. 2010. How can the use of blog software facilitate the writing process of English language learners?.Computer Assisted

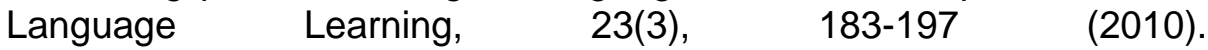
http://dx.doi.org/10.1080/09588221.2010.486575.

T., Miyazoe, \& T., Anderson. 2010. Learning outcomes and students' perceptions of online writing: Simultaneous implementation of a forum, blog, and wiki in an EFL blended learning setting. System 38, pp. 185199, Elsevier Ltd. 